\title{
FRANCES PERKINS: A LIFE OF COMMITMENT
}

\author{
ANTONIO DANIEL JUAN RUBIO \\ Universidad de Alicante
}

Recibido: $17 / 5 / 2010$

Aceptado: 19/10/2010

\section{Resumen}

Este texto pretende presentar un retrato global de una mujer casi desconocida. Frances Perkins fue promotora e instigadora de la mayoría de las medidas sociales durante la Gran Depresión en Estados Unidos, conjunto de acciones comúnmente conocidas como «The New Deal». Además fue la primera mujer en la historia norteamericana en obtener el estatus de ministra, convirtiéndose en Ministra de Trabajo durante las cuatro administraciones de Roosevelt.

Palabras clave: Ministra de trabajo, trabajadora social, seguridad social, legislación laboral.

\begin{abstract}
This paper aims at presenting an overall portrait of an almost unknown woman. Frances Perkins was both the promoter and instigator of most of the social policies during the Great Depression in the United States, commonly known as «The New Deal». She was also the first woman in US history to gain the status of Cabinet Member, becoming Secretary of Labor for the whole four Roosevelt's administrations.
\end{abstract}

Keywords: Secretary of Labour, social worker, social security, labour legislation.

Feminismo/s 16, diciembre 2010, pp. 159-179 

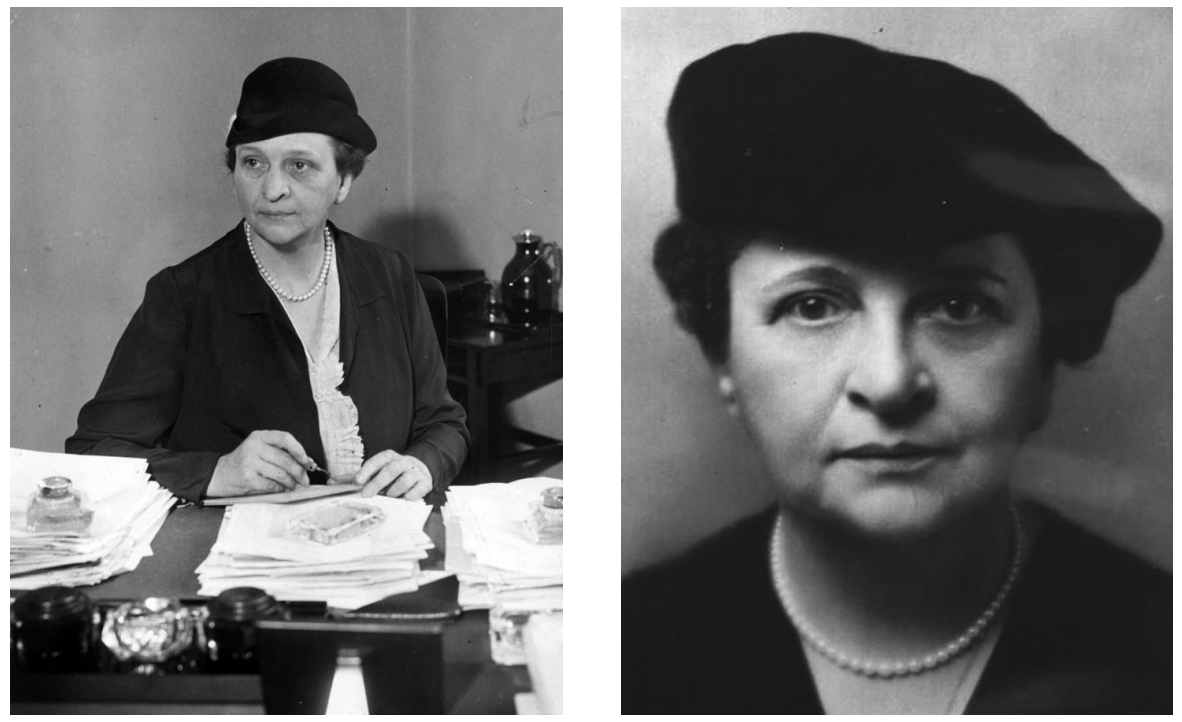

Frances Perkins 


\section{Introduction}

Frances Perkins had a quite long career as teacher, social worker, reformer, chairwoman of New York State's Industrial Board, and finally became the first woman cabinet member in the history of the United States under President Franklin D. Roosevelt. Despite all the different posts and tasks throughout her life, Perkins refused to consider her sex an obstacle to a deep and continuous involvement in public life. Besides, all these rather confirm her determination and commitment to a purpose, that of betterment of existing human conditions in the United States, and by extension, in all over the world.

Frances Perkins is characterized by her strength of character, her leadership, and her dedication to social welfare causes and diverse concepts, which are now taken for granted in most countries, if not all, such as women's rights, child labour laws, unemployment insurance, and social security for the elderly, but which were considered revolutionary in the 30's.

Perkins never doubted that Roosevelt would occupy the White House, but she really entertained no illusions of joining him in a position of national eminence and relevance. Up to then, her work had been centred on New York State and her family life and social activities tied her to New York City. When she was appointed Secretary of Labour, Perkins was a robust and energetic woman in her early fifties with thirty years of experience to qualify her for the work. Her reluctance to accept the post had been genuine at first, but she later admitted that she had to accept the appointment proposed simply because no other woman had ever been asked to do it before in the United States. At the very first meeting, members of the Cabinet shared a sense of nervous excitement as they took their places as the «board of directors of the nation», and some of them expressed their reservations about the premature recognition of a woman, on a clear reference to Frances Perkins.

Because of her will to help others, she was often labelled a «revolutionist», and her hats served as a trademark and a symbolic conversation piece that identified her with the Revolutionary period in American history. 


\section{Academic formation (1880-1910)}

She was born Fannie C. Perkins in Boston according to a certified copy of the birth certificate on April 10 1880, becoming years later Frances Perkins. Fanny Perkins grew up in Worcester (Massachusetts). Her mother, Susan Perkins, ran a hospitable home in Worcester. Fred Perkins, her father, was an amateur scholar who loved to read Greek poetry.

Despite her parents' dispute over her immediate future, she was allowed to apply for admission to Mount Holyoke College, even though higher education was not considered fair from the norms of society at the time for a middle-class girl. Although her marks at College were not always good, she took the hardest courses and passed them. This gave Perkins confidence and built her character for the nearby future in which she learned how to overcome the difficulties. In addition, she brought them to life by sending students over to the factories in the area around for information on economic and social problems.

This was her first approach to the socio-economic realities of society. For the first time, Perkins understood the social revolution she had previously witnessed in Worcester, and history became to her more than mere date and events. A classmate, Louise Rounds, described her as «an individual who refused to conform to customs and traditions of college life, always ready to stand for her convictions and take the consequences of her opinions» ${ }^{1}$.

Despite her yearning for something more challenging, in the fall of 1904, Frances accepted a teaching position at an exclusive boarding school, Ferry Hall, in Lake Forest (Illinois). There she taught physics and biology, and handled laboratory work, and she also wrote short stories on her free time. She resigned and became a temporary resident of Chicago Commons where she received an education from Jane Addams and her colleagues.

In the fall of 1907, she began her duties as the General Secretary of the Philadelphia Research and Protective Association. At that time, one of her most traumatic experiences was dealing with the explotation of European immigrants and especially Southern black girls. This is really where Frances Perkins began her predilection for the systematic study of social problems. She completed a comprehensive analysis of the conditions under which working women lived in Philadelphia for the International Research Bureau. The most specific subjects of her analysis and attacks were the lodging houses that charged the workers the salary of half a week.

1. Keller, Emily. Frances Perkins. First Woman Cabinet Member. North Carolina, Morgan Reynolds, 2006, p. 19. 
With the help of Simon P. Patten, she won a fellowship to Columbia University in New York City. Perkins planned to learn how to conduct surveys and other methods of social research, and she expected to earn a master's degree in the new field of sociology. She finally received her master's degree in economic and sociology two months later. As she spent time writing reports, she discovered that she was also a skilled orator. Consequently, she spoke to teachers' conventions about child labour laws, as she will do at the end of her career.

\section{Early career as a social worker (1910-1918)}

As a graduate student, Perkins managed to balance her activities so that she maintained her friendships and she also received high grades at school. She read, studied, wrote, and went to the opera or to the theatre, or dined with friends or appointments. More than any other settlement, the Henry Street Settlement House figured most significantly in the life of Perkins. Here Frances met the people who would influence the direction of her professional career, and by this time, she came to meet Lillian Wald, the person who had established the Henry Street Settlement House as a nursing service in 1893.

By joining the Consumers League, Perkins made a serious commitment that had her plunging into investigative activities immediately. In a matter of months, her dedication and efforts were rewarded by her election by the board to the position of Executive Secretary of the New York. For her efforts on the Civic Organizations' Conference on Public Safety, Frances was named Secretary, and as such, many of her recommendations for improving proposed factory legislation were included in the Report of the Factory Investigating Commission: "We expect to derive frequent aid in the treatment and solution of our problems in the field of labour». ${ }^{2}$ Perkins continued her salaried job with the National Consumers League and she also spoke to many different organizations about the need for child labour laws. Frances accepted an invitation to teach sociology at Adelphi College, which showed her firm determination to cope with her personal formation and her commitment to her professional career at the same time.

Probably the most private part of Perkins' life was her marriage to Paul C. Wilson in September 1913. The date when Paul C. Wilson proposed marriage to Frances Perkins is a matter of conjecture, but the spring of 1913 seems to be the most accurate. After a time, she decided to accept Wilson's proposal

2. Colman, Penny. The Achievements of Frances Perkins. New York, Maxwell Macmillan International, 1993, p. 56.

Feminismo/s 16, diciembre 2010, pp. 159-179 
for marriage. She felt that it was right to retain her own name for professional purposes on the ground that she had already made a place as Frances Perkins, whereas if she were to call herself Mrs. Wilson, she would have to set back in her career right from the beginning. In 1914 she also found herself coined as a revolutionist for her quotation: «feminism is revolution, I am a revolutionist, and I believe in revolution as a principle» ${ }^{3}$.

In April 1917, the United States entered World War I in order to end wars. Being a mother did not mean to her that she could deny her responsibility to her country, so she accepted the position of Executive Director of the New York Council of Organization for War Service. Soon after, a group of nine women, which obviously included Frances Perkins, founded the Maternity Centre Association. But as Perkins spent time with the organization, her husband became ill. From then onwards, Perkins realized that she would have to take responsibility for the family's finances due to Wilson's weakness and illness.

\section{Professional career as an industrial worker in New York (1919-1932)}

In 1919, Al Smith offered Perkins to be a member of the Industrial Commission of the State of New York, which was created to follow up on the laws and regulations that had been passed to improve the working conditions in the factories of New York and other businesses alike. This was the first appointment of a woman under the new political conditions in the State. The idea was startling to Perkins as no woman before had ever been appointed to anything but an advisory board. And Frances certainly saw the industrial commissionership as an opportunity; the unprecedented salary almost quadrupled the national average family income. Al Smith solid support to Perkins proved decisive, and he defended her at all costs when he overtly declared: «there are millions of working girls in this state and the industrial commission for that reason ought to have a woman in its membership, and I could think of no one better fitted by knowledge and ability than Miss Perkins» ${ }^{4}$.

In 1922, the Women's Division of the State Democratic Party under Belle Moskowitz, and with Frances Perkins and Eleanor Roosevelt, pitched in with vigour in Al Smith's campaign for governor in 1922, making their voices heard throughout the state. The result was that Al Smith won the election handily. Consequently, Perkins continued her position with the Industrial Board. Although she was sympathetic to Smith after his defeat, Perkins was pleased

3. KeLler, Emily. Op. cit., p. 41.

4. Ibid., p. 55. 
when F. D. Roosevelt won the election for state governor of New York in 1938 by a small margin of votes. This would mean the next step in Perkins' career, and her progression along the political arena.

Frances Perkins was asked to go on with Roosevelt as Industrial Commissioner, a cabinet-level position that came with some executive duties. This was an unexpected promotion for her career. In January 1929, nearly 1.000 people honoured Frances Perkins at a luncheon in the city of New York when she sworn the post. Apparently, she set aside her prepared speech and spoke on the most personal level ever recorded, describing herself as symbolizing the efforts of the many who shared the idea with her that social justice is possible.

Perkins had a personal interest in industrial safety and was anxious to find ways to reduce the human factor responsible for so many tragic accidents: «people who are exposed to dangerous machinery day in and day out, have got to develop some new power of co-ordination which will enable them automatically to carry out their work in a safe way» ${ }^{5}$. However, it was difficult for most people, including the members of Hoover's Cabinet, to see the danger signs amidst the apparent prosperity of the 1920s. In April, Roosevelt sent into motion the first state-organized system of relief for the poor, recognizing that the magnitude of the problem was making it impossible for communities to care on a merely private charity basis.

But the situation worsened, so Perkins set up an advisory committee to make recommendations for a state public employment service. The era of permanent prosperity had been short and the deepest economic depression in the history of the United States was at first hand. In its wake, a flood of panic and despair soon spread across the entire nation. As Perkins once told Governor Roosevelt: «we are not just dealing with mere figures on paper, but with human beings, men, women and children who are out of work and hungry» ${ }^{6}$. And Roosevelt could not agree with her any more, and with Perkins' help he presented several reform bills to the legislature of New York which included legislation to establish old-age pensions, unemployment insurance and shorter work week. When asked about the most serious of the problems demanding attention, she answered that «the human one of no work, no wages, no buying power is really the most crucial since our present social organization rests upon industrial mass production. And mass production has

5. MoHr, Lillian H. Frances Perkins. That Woman in FDR's Cabinet. Washington, North River Press, 1979, p. 84.

6. Ibíd., p. 92.

Feminismo/s 16, diciembre 2010, pp. 159-179 
as its corollary mass consumption, but mass consumption means that the wage earners must be able to buy» ${ }^{7}$.

\section{Professional career as a secretary of labour in Washington (1933-1945)}

By this time, the country was already fed up with President Herbert Hoover and the ongoing depression. The people of the United States were now ready for a change and a new leader, and F. D. Roosevelt was their man, so he decided to run against Hoover in the 1932 presidential election. In November 1932, Roosevelt was elected President in a landslide victory over Hoover. People voted overwhelmingly for what Roosevelt had called a «New Deal» in his speech. Mary W. Dewson told Roosevelt: «only one thing I'll ask for you, and don't give me the answer now, Frances Perkins as Secretary of Labour ${ }^{8}$. Only a few expressed their reservation to the appointment. Mainly they came on the ground that they thought it was too early to put a woman in the Cabinet at that time. Women had won the right to vote in 1920, but still most people felt that a woman's place was at home.

Roosevelt was aware of her background, progressive views, efficiency, and intelligence which had led him to appoint her the Industrial Commissioner of New York State. Roosevelt agreed in principle with his wife Eleanor that if any woman in the world was equipped by experience and ability to be the first woman Cabinet member, Frances Perkins certainly was that woman. It was surprising how many people wanted her for Secretary of Labour. Theirs was an easy give-and-take conversation. Roosevelt liked Perkins as a woman because she did not trade on the fact that she was a woman. They focused their attention on immediate problems such as child labour laws, workmen's compensation, relief programs and social security.

Perkins first mass press interview went badly. The twenty reporters crowding around her desk ignored her patient displeasure with personal questions, and finally she explicitly requested that they desisted from exploiting those of her family not in official life. She found the prying of reporters insufferable and her introduction in public office was less than fortuitous.

Perhaps Perkins' first term in office, as Secretary of Labour, is the most relevant and important for its significance and the number of measures taken, either with or without success, in order to cope with the Great Depression and its economic consequences: «The fact that we still do not have universal

7. Ibíd., p.101.

8. Ibíd., p.107. 
coverage is an indication that it would have been just as well to go ahead with the whole program $» .^{9}$

After taking the oath of office, Roosevelt began his productive first 100 days in office. He closely worked with his Cabinet members, aides, economists, and professors to craft several pieces of legislation that altered forever the relationship between citizens, business, and government. As Secretary of Labour, in testimony before a legislative committee, Frances Perkins spoke of the Depression in terms of human misery rather than in economic and political terms. She reported that many families suffered from malnutrition and hereby predicted that the full effects of the Depression would not be seen for several years.

Perkins's first official act was the elimination of case fixing and the terrorization of aliens coming into the States. She regarded the location of the Immigration and Naturalization Service on the Department of Labour as more a matter of historical accident and convenience than of necessity. As a result, she had the President send an executive order to Congress in June to facilitate the consolidation of the Bureaus of Immigration and of Naturalization in the interests of efficiency and economy. It was not until 1940 that the service was removed, and became part of the Department of Justice: «The United States recognised the desirability of international cooperation in matters pertaining to labour». ${ }^{10}$

Perkins' responsibility was not only on the Department of Labour, but also she served simultaneously as a member of President Roosevelt's Inner Cabinet, which meant that her counsel was sought regarding national policy and frequently not directly pertinent to her department. Perkins created a nationwide system of free employment agencies, known as the US Employment Service. Within four years, 19 million people found jobs throughout this service. She also prohibited the Employment Service from racially discriminating against job seekers.

Roosevelt had an idea for putting men to work that he tested on Perkins during their first weeks in office. She listened carefully to his plans for a national reforestation program, the Civilian Conservation Corps (CCC), and she immediately knew that the Department of Labour could not handle such a program alone. The CCC offered young men between seventeen and twentythree food and clothing, and medical care in exchange for working at jobs to clean up and improve the national parks and forests. Plaques acknowledging

9. PERKINS, Frances. The Roosevelt I Knew. New York, The Viking Press, 1946, p. 298.

10. Lawson, Don. Frances Perkins: First Lady of the Cabinet. New York, Abeland-Schuman, 1966, p. 143.

Feminismo/s 16, diciembre 2010, pp. 159-179 
the workers can still be found in US national parks and forests. Frances announced then the formation of a CCC camp for unemployed young women in New York. By the end of 1933, almost every state would have an office that helped recruit labour for the CCC.

The Federal Emergency Relief Administration gave grants to states to provide food, clothing, fuel, medicine, housing and other basic necessities for the unemployed, and Perkins was very much involved in the development of this program. Distributing relief money to the unemployed was one tactic Roosevelt and Perkins tried. Another one would be reemploying them in the service of the federal government. They called for a new program that combined conservation with job relief.

As Roosevelt's neared the end of his first 100 days in office, Congress passed the National Industrial Recovery Act (NIRA), which Perkins worked long hours helping to draft the legislation. The NIRA included a federal public works program called the Public Works Administration (PWA) which provided jobs for the unemployed by hiring them to work on public construction projects. Perkins' most significant contribution to the welfare of both organized and unorganized labour took form in the NIRA which decreed that «employers shall comply with a maximum hours of labour, minimum rates of pay, and other conditions of employment approved or prescribed by the President $»^{11}$. Organized labour received a spur that provided employees with the right to organize and bargain collectively through representatives of their own choosing.

During the twelve years that Perkins was Secretary of Labour, she worked with and helped settle many labour disputes for which she was criticized as being too pro-labour. Despite these accusations, she never wavered in her insistence that strikes and disputes should be settled by negotiation, conciliation and mutual agreement and understanding. She promoted the formation of consumer groups across the country, and encouraged them to report consumer concerns to her. She was a wise choice for the first consumer's voice officially introduced into the federal government.

The Roosevelt administration continued to push antipoverty legislation well past the first 100 days of presidency, and Perkins continued to be a part of the efforts for years. In late 1933 and early 1934, she worked hard to achieve two more of her goals: to establish unemployment insurance and old-age insurance.

11. MOHR, Lillian H. Op. cit., p. 143.

Feminismo/s 16, diciembre 2010, pp. 159-179 
Frances Perkins was the first Secretary of Labour who made labour leaders uneasy until they realized that she was doing the job that a Secretary of Labour is supposed to do, looking after the interests of labour, a quite new experience for most of them. In keeping with the intent of the act, Perkins emphasized promotion of the welfare of all the workers, not just union members. She found that many people were astonished to learn that the moral aspiration for the welfare of working people was also an economic law. This was a new idea, and as an economist, Perkins visualized improved standards of living through increased consumption.

From the beginning to the end of the New Deal administration, programs and projects developed in a dozen directions simultaneously. Labour was an integral part of these and appropriately the Secretary of Labour's voice was heard on most of these matters.

Perkins' interest in the children of the nation never decreased. She urged people to write to their state governors if their states had not yet ratified the child labour amendment to the federal constitution. Although Perkins usually refused to defend herself against personal attacks by the press, she spontaneously reacted against articles and critics attacking the child labour amendment. Perkins' concern for children took another direction. She brought about a piece of legislation that ended discrimination based on sex that affected children in the matter of naturalization, which the House of Representatives passed in April 1934, and finally the Senate in May.

In the summer of 1934, Roosevelt created the Committee on Economic Security (CES) composed of various Cabinet members: the Secretary of the Treasury, the Secretary of Agriculture, the Attorney General, the Federal Emergency Relief Administrator, and the Secretary of Labour as its chairman. Roosevelt wanted that the CES developed a comprehensive social security program for workers that included unemployment insurance and old-age insurance. Chairing the CES was the culmination of a lifetime's work for Perkins. She and the President agreed that the committee should take a broad approach to the issue of economic security for all workers. The CES also reported on the status of health insurance, workmen's compensation, and specialized types of public assistance for specific groups.

For months, Perkins had been educating the American public on the significance of the Social Security program through speeches, articles and radio addresses. She made sure that the constituents of the senators and the representatives were well informed on the basic key concepts. But not everyone was persuaded to easily accept the socialistic program that she promoted. The Social Security Act which was finally passed contained ten programs, 
including public assistance to the blind and to the children without parental support. In August 1935, Perkins was to be honoured by being issued the first Social Security number and card, but this honour she hastily declined: «The Social Security Act constitutes a truly forward looking measure for the protection of millions of people». ${ }^{12}$ On Labour Day 1935, Frances Perkins gave a talk over a national network on the newly passed Social Security law: «the passage of this act is deeply significant of the progress which the American people have made in thought in the social field $»^{13}$.

Frances Perkins set up a Division of Labour Standards. The division outlined as its objectives to study specific and local problems and to make recommendations on industrial sanitation, health and safety, security, wages, working hours, housing, vocational education, and community opportunity among others issues.

The United States joined the International Labour Organization (ILO) in June 1934. Without Perkins, the US membership in the ILO would never have been taken since she gave the ILO full support, and besides, she enlisted others. The Congress of the International Federation of Business and Professional Women honoured Perkins as the «world's outstanding woman» in the summer of 1936 while she was away on holiday across Europe.

In the meantime, Perkins faced more pressing issues when two pieces of New Deal legislation, the NRA of 1933 and the Wagner Act of 1935 had created tensions between labour and management. One important section of the NRA gave labourers the legal right to organize and bargain collectively with employers over pay rates, job conditions and other workplace issues. So during the first year of the NRA, more than one million workers joined labour unions.

In November 1936, F. D. Roosevelt was re-elected President of the United States in a massive victory. Roosevelt asked Perkins to continue as Secretary of Labour but she at first shied away the offer. She thought that perhaps her resignation would be the best way to end the industrial strikes across the nation since her negotiations with the ALF (William Green) and the CIO (John L. Lewis) turned out to be unsuccessful. Yet Roosevelt insisted that Perkins worked with him, and she agreed to stay on for another term as Secretary of Labour. But despite the administration's effort and the millions of dollars pumped into the economy, recession hit in the 1937-1938 period.

12. Martin, George. Madam Secretary: Frances Perkins. Boston, Houghton Mifflin Company, 1976, p. 233.

13. MoHr, Lillian H. Op. cit., p. 212. 
Perkins' first term in office had been characterized by the strong support and reinforcement laid over her by the President, and by the enormous quantity of measures directed towards the improvement of the economic situation and the relief and recovery of the social legislation. However, this second term will be marked by just the counterpart measures. It is in this second term when she first presented her resignation to the President due to an impeachment process, though not accepted, and when she saw her authority dismissed and declined. Since fundamental issue remained unresolved in the interpretation of the Immigration Act, the Bridges hearings were postponed on the advice of the Department of Justice. In May 1938, the Committee on Un-American Activities was formed in the House of Representatives to investigate possible communist activities in America.

While the American public preferred to look the other way, the President and his Cabinet attempted to alert the nation to the catastrophic events taking place abroad. Perkins' pronouncements tended to be more serious than the editors of college papers considered fair: «For Roosevelt the war years began in 1939, but the war problem had begun long before that for him». ${ }^{14}$ By the end of 1939, most of the western world was at a state of war, but the United States remained neutral although it was clearly on the side of Great Britain and the other allies opposed to the Axis (Germany, Italy and Japan). Not until December did public opinion polls show that neutrality on World War II had displaced unemployment as the greatest concern of the American people. By 1940, this anxiety heightened, providing the rationale for the President's defiance of the two-term tradition.

The US Employment Service was moved from the Department of Labour to the Federal Security Agency. William Green of the AFL fully supported Perkins and her vain objections to this breakage of authority. The public interpreted the change as a punishment for Perkins as this could not have come at a politically worse time for her.

That year Roosevelt became the first president to run for a third term. Although Perkins did not approve of Roosevelt running for a third time, she concluded that no one else had his ability in a war crisis. She was convinced that the major work of the New Deal could be completed by him. In November, Roosevelt easily won the re-election. Perkins had planned to resign as Secretary of Labour, but again Roosevelt refused to accept her resignation, just because he simply needed her loyalty at those difficult times.

14. Perkins, Frances. Op. cit., p. 347.

Feminismo/s 16, diciembre 2010, pp. 159-179 
This term saw the participation of the United States into World War II. For obvious reasons, the focus of the President and the Cabinet turned from social and economic legislation to the war efforts, though Perkins kept on insisting on the improvement of the labour conditions. Although the United States was officially neutral, Roosevelt declared a national emergency in May 1941. In the cabinet meeting held, it was agreed that Congress would be asked to declare war on Japan after being informed by the Secretary of the Navy on what had really happened. And the new war would make tremendous demands on American labour. At Perkins' recommendation, the President signed an executive order establishing the National War Labour Board. Perkins also attacked another culprit, industrial and traffic accidents, and encouraged him to give his blessings to the efforts of the National Safety Council.

In 1944, Roosevelt sought a fourth term as president. As a war-time President, he insisted that this was not the time for the nation to change leaders. Perkins had seen him less often and for shorter periods during the war years since his focus was now on foreign and military affairs. In reality, Roosevelt's health was rather poor, but his physician never let anyone know how ill he was. He had a weak heart and was subject to fainting fits and he may well have suffered also minor strokes. Despite his health problems, Roosevelt was not ready to leave office yet.

The following month, F. D. Roosevelt won his fourth term of office, and once again, Perkins wrote a documentary letter of resignation. But since the President did not find anyone with the unanimous backing of the labour movement, he admitted that he could not let her go on the eve of his inauguration speech. This fourth and last term in office of Frances Perkins was both the shortest and the saddest. The shortest because she did not get to fulfil even a year in office, and the saddest because of all what meant F. D. Roosevelt's death and his replacement by Harry Truman. In April 1945, President Roosevelt died in Georgia where he went to relax and to treat his polio illness. Despite the horrendous effect the news made on most people, Perkins never lost her affection or admiration for him.

\section{Professional career as a civil service commissioner (1946-1952)}

After Roosevelt's sudden death, Vice-president Harry Truman assumed the role of President. Once again, as it was already usual in her, Perkins offered Truman her resignation although he asked her to stay on until July 1945. Perkins, who had been a pioneer in labour reform, served an extraordinary twelve years as Secretary of Labour. Of the original New Deal Cabinet of 1933, only the Secretary of the Interior, Harold Ickes, put in more time than her. 
Truman thus agreed to send Perkins as a government representative to the International Labour Organization (ILO) in Paris. Beyond that fact, her definite break with the Department of Labour was now complete.

In September, Truman conferred with Frances Perkins and, although she did not intend to resume working for the government, she was appointed to the Civil Service Commission. This appointment was, for obvious reasons, subject to the approval of the Senate. Perkins took the oath of office in October 1946 on an interim basis. After unanimous approval by the Senate Civil Service Committee, her nomination went directly to the Senate in January 1947.

As a commissioner, Perkins' major functions were to visit periodically the fourteen regional Civil Service offices, to make speeches, to assist in the development of competitive examinations, to work with the Loyalty Review Board and to eliminate inefficiency and fraud by promulgating rules and regulations governing the lives of federal workers: «What difference does it make to us if a man entertains ladies in his room? How is that going to affect on his ability to do his job?» ${ }^{15}$

In March 1952, President Truman signed an executive order exempting Frances Perkins from compulsory retirement from government posts when she would be seventy years of age. Of course, she had completely ignored the mandatory retirement age. Paul C. Wilson unfortunately died in December 1952. Services in his memorial were held in St Andrews' Church in Maine, and the burial was organized in the family Glidden cemetery there. President Truman wrote a touching and heartbreaking letter of condolence to her.

\section{Lecturer career (1953-1965)}

On Inauguration day, January 20 1953, Perkins submitted her letter of resignation from the Civil Service Commission to Dwight D. Eisenhower, who was the first Republican President in twenty years. She then filled out an application for a Social Security number and boasted of her new job as a great lecturer at the University of Illinois. She was lucky to live at a time when the United States was ready for social reforms, and she was lucky to live in a period when women finally got a change to serve in public life without hesitation or disturbance.

Although she was seventy-three, Perkins did not still want to retire, so she accepted an invitation to lecture at the University of Illinois where she

15. SEVERn, Bill. Frances Perkins: A Member of the Cabinet. New York, Hawthorne Books, 1976, p. 378.

Feminismo/s 16, diciembre 2010, pp. 159-179 
held twelve seminar meetings about the Department of Labour and the labour movement during the New Deal. She also gave some university lectures on the figure of F. D. Roosevelt for her talent as a lecturer, which won her several return appearances along the season. More and more engagements followed, and suddenly she had found a new career and a new challenge.

In 1955, she inexorably found that her lifestyle required more money than her current income permitted, so she was delighted by the invitation of the School of Labour and Industrial Relations at Cornell University in Ithaca (New York) to serve as a visiting professor. There she enjoyed most of the students, particularly those whose questions triggered memories of her early days and of the New Deal era under F. D. Roosevelt. Nonetheless, many of the questions made were rather placed at a basic level. «What is my duty? There is always much to be done. I am not going to be doing it. It is up to you to contribute some small part to a program of human betterment for all time». ${ }^{16}$

In addition to her work at Cornell, she agreed to lecture in different universities in Salzburg (Austria) and Bologna (Italy). In the spring of 1960, Perkins received an offer from the member of the Telluride Association at Cornell to be a resident lecturer. She would live at Telluride House, a residence for students on scholarships in the campus. She accepted immediately the honourable proposal for being the first woman ever to live in the house. She enjoyed being called "professor» by her students because it gave her something to live up to. Even in her eighties, she knelt down at appropriate times during the Episcopalian services held, making no concessions to the physical limitations and weaknesses of her age. Nobody knew that she was suffering from arterial-sclerotic and hypertensive heart disease. She tried at all costs to conceal the fact that her vision was so poor that even reading proved difficult without a magnifying glass.

After a summer spent mostly in Maine, Perkins resumed her role as a visiting lecturer at Cornell. Her sensitivity about age did not keep her from stipulating in her will that a contribution of money from her estate went to the class of 1902 fund from Mount Holyoke. Frances continued to make speeches to different teachers' associations and social workers' meetings, and she also appeared on special programs at Cornell University while she was as well keeping up her guest lectures.

Perkins caught a cold while on attending the inauguration of Lyndon B. Johnson as President in January 1965. It hung on but it did not discourage her and she celebrated her $85^{\text {th }}$ birthday in next April. She went to see her

16. Perkins, Frances. People at Work. New York, The John Day Company, 1934, p. 267. 
New York City doctor about her cold and entered Midtown Hospital on May $7^{\text {th }}$, according to her expectations, just to clear out her lungs as she had said. Regrettably, she suffered a severe stroke on May $14^{\text {th }}$ from which she never regained consciousness and she passed away a few days later. A solemn requiem mass was celebrated at the Episcopal Church of the Resurrection in the city of New York, the city which had witnessed her personal growth first, and her professional development later. Her remains were sent to Maine to be buried in the family plot.

\section{Perkins' sway as a political symbol}

Alongside her political career, Perkins worked for seven years under Governor Al Smith, sixteen years under the presidency of Franklin D. Roosevelt, and six and a half years under the presidency of Harry S. Truman. When Roosevelt promised to back several programs proposed by Perkins in 1929, she immediately took over the post of Industrial Commissioner of New York, becoming then the first woman member of a state cabinet. Besides, when the then Governor of New York got to the presidency, he thought of Perkins for the post of Secretary of Labour. Her appraisal took place in 1934, being an important point in history for setting the pace for further women to take posts along the federal administration. Her renderings as Secretary of Labour were quite amazing at the period because she became the first female cabinet member in the history of the United States.

Perkins was a very active and outspoken person in the deployment of her many different functions and posts. She was the person responsible for the development of important legislative measures for the country such as the Social Security Act. On several occasions, Perkins set out the necessity of the abolition of child labour and its own regulation in order to put a limit to the children working age as well as to improve and regulate the existing working conditions. She was one of the first persons to consider and speak out in favour of improving working conditions.

Perkins was deeply concerned with the subject of social security for the workers in general. The issue of social security was one of her key landmarks along her career, which was culminated with the passing of the Social Security Act in 1935. In spite of its many limitations, this act made up of the greatest milestones of the policies of the New Deal, bringing lasting changes for ever in the economic role developed by the federal government. The passing of this act meant the recognition and improvement of the social conditions of workers in the US, and it was the precursors of the modern social security system existing in the country. 
Before this law was enacted, social security was almost non-existent in the United Stated with the exception of the compensation for labour accidents. From then onwards, the federal government acquired a series of compromises with the society, thanks in great measure to the task carried by Francis Perkins. Nonetheless, according to Perkins this act missed out a complete coverup for all American workers, having an incomplete program of deployment. In Perkins' view, this act came to be little ambitious scarcely contemplating some of the many social evils developed in its carrying out.

What it mainly lacked, following Perkins' doctrine, was a complete coverup for the whole mass of workers, not only to half of them. Perkins thought that this complete cover-up was to be already achieved by 1935. Nevertheless, this Social Security Act was rooted by Perkins as one of the most significant landmarks of federal legislation during the presidency of Roosevelt. In her opinion, this act represented a democratic and humanitarian achievement which had contributed to improve the plain condition of life in the United States: «I think in this period of unemployment, when we see the disaster and the human wreckage caused by insecurity, we begin to realise the importance of developing somehow in our economic life security against old age and unemployment». ${ }^{17}$ Frances Perkins worked almost exclusively for two years on the design, development, and establishment of this act until it was finally signed by President Roosevelt in 1935 in an effort to alleviate the conditions of the average worker.

Perkins' second landmark was her effort to improve the general situation and condition of children, putting all her energies in improving the wellbeing of both children and mothers. She was the first secretary seeking to investigate the industrial conditions trying to protect workers in general. Perkins was regarded as a pioneer in the field of labour reform and legislation in the country, all her life she fought for the improvement and betterment of existing working conditions.

During all her political career, she was always placed on behalf of the workers, whether syndicated or not, in the elaboration of statutes of different social measures passed by the federal government. Perkins sought the possibility and necessity of the abolishment of child labour and its proper regulation so as to limit the working age and to improve its conditions. She knew that the fight to maintain labour standards would never end. She argued that the US was some decade behind Europe on behalf of the protection and care

17. MYERS, Elisabeth. Madam Secretary: Frances Perkins. New York, Julian Messner, 1972, p. 412. 
given to the less favoured groups, and that something had to be done, and done it fast.

Another relevant innovation suggested and put forward by Perkins was her struggle to include the minimum wage in the social legislation of the New Deal. With her constant effort and that of some others, the Government Contracts Act was signed in 1936 to regulate all public contracts, and minimum conditions in the public employment. This act was the precursor of the Fair Labour Standards Act, passed in 1938, which attempted to stipulate a minimum wage and a maximum workday for all workers. Besides, it added the surplus of the payment for any overtime activity carried. These acts shared the basic principle that the federal government could and should establish a minimum wage and a maximum workday limit for all American workers as well as abolish child workforce in certain industries.

Perkins played a key and relevant role in the different governments and cabinets under the presidency of Franklin D. Roosevelt, becoming one of the references for the rest of women. It would take twenty years before another American President, Dwight Eisenhower, appointed a woman, Oreta C. Hobby, to the cabinet position of Secretary of Health, Education and Welfare. Since then, women have been appointed to several cabinet-level positions and have been elected to the Senate and to the House of Representatives of the US. Women have been elected as well as governors of several states in the union.

It is also outstanding Perkins' personal back-up of several key measures of the social legislation put forward and abridged by the New Deal. Among some measures, Perkins got the appraisal of dealings aimed at the improvement and betterment of the social conditions of workers. Frances Perkins must be regarded as the pioneer in the field of social reform and legislation in the United States, and the one who fought to achieve a social security act, a minimum wage, a maximum workday, and safe working conditions as well as to erase child workforce.

\section{Conclusions}

Trying to resume Frances Perkins' life in just a few lines seems a rather impossible mission for the extension, variety, disposal and commitment she had posed over the country along the years. For 25 years, Perkins' career as a social worker and as a civil servant was the centre of social reform activities.

Frances Perkins was the first woman cabinet member. As Secretary of Labour from March 1933 to July 1945, she also served longer than any other Secretary. She was an outstanding career woman, and an outstanding individual and a public official whose work profoundly changed the lives of all 
Americans. She was the author of two books People at Work (1934) and The Roosevelt I Knew (1946), in addition to innumerable other studies and speeches. She was trained as a teacher, and taught at various universities throughout her lifetime. Her character combined a very strong sense of mission in pursuing social justice with a pragmatic bent, which helped her to appraise the political realities of a situation and get things through.

Her views were decidedly liberal and she valued individual liberty. That also applied to her own privacy. As a public official for a good portion of her life, she devoted her efforts without hesitation to enhancing the public welfare, but she also insisted on keeping her personal life with her husband and daughter quite separate from her public responsibilities.

Frances Perkins quickly perceived that World War II meant a most spectacular change in drawing large numbers of women into the labour force, and into occupations previously held exclusively by men. She felt that the war pressures were leading to some breakdown of prejudices against certain types of women, such as married women, black women, and older women.

She brought to her office a deep commitment to improving the lives of workers and creating a legitimate role for labour unions in the American society. She embraced the values of economic justice and security for all Americans. She never stopped believing that legislation was the best way to right industrial wrongs and she came to accept the value of working-class organization.

Thereafter, she continued to lead an energetic life of teaching, public speaking and writing. At the age of 80 she gave a memorable speech to the employees of the Social Security Administration on The Roots of Social Security. She lectured at Cornell University, although her health was failing, until two weeks before she died.

\section{Bibliography}

Primary Sources

Perkins, Frances. People at Work. New York, The John Day Company, 1934.

- The Roosevelt I Knew. New York, The Viking Press, 1946.

Secondary Sources

Brown, Douglas. The Genesis of Social Security in America. Princeton, Princeton University, 1969.

ChamberLain, Neil. Sourcebook on Labour. New York, McGraw-Hill Books, 1958. 
Colman, Penny. The Achievements of Frances Perkins. New York, Maxwell MacMillan International, 1993.

Cussler, Margaret. The Woman Executive. New York, Harcourt, Brace \& Co., 1958.

FEnNo, Richard F. The President's Cabinet. Cambridge, Harvard University Press, 1959.

Gruberg, Martin. Women in American Politics. Wisconsin, Academia Press, 1968.

Keller, Emily. Frances Perkins: First Woman Cabinet Member. North Carolina, Morgan Reynolds Publishing, 2006.

LaWson, Don. Frances Perkins: First Lady of the Cabinet. New York, Abelard-Schuman, 1966.

Learned, Henry B. The President's Cabinet. New Haven, Yale University Press, 1912.

LEED, John H. Government and Labour in the United States. New York, Rinehart \& Co., 1952.

LOMBARDI, John. Labour's Voice in the Cabinet. New York, Columbia University Press, 1942.

Martin, George. Madam Secretary: Frances Perkins. Boston, Houghton Mifflin Company, 1976.

MoHr, Lillian H. Frances Perkins: That Woman in FDR's Cabinet. Caroline, North River Press, 1979.

MYers, Elisabeth. Madam Secretary: Frances Perkins. New York, Julian Messner, 1972.

Roosevelt, Eleanor. Ladies of Courage. New York, Putnam's Sons, 1954.

SEVERn, Bill. Frances Perkins: A Member of the Cabinet. New York. Hawthorne Books, 1976. 